\title{
FULL PAPER
}

\section{Voxel generation}

Raising awareness for informatics and society among high-school pupils through a game-design project

\section{Voxel Generation}

Sensibilisierung für Informatik und Gesellschaft von Schülerlnnen Höherer Schulen durch ein Game-Design-Projekt

Vera Schwarz, Gerit Götzenbrucker, Fares Kayali, Christiane Grill \& Peter Purgathofer 
Vera Schwarz (Mag.), Department of Political Science, University of Vienna, Universitätsstraße 7, 1010 Vienna, Austria \& Department of Communication, University of Vienna, Währingerstraße 29, 1090 Vienna, Austria; Contact: vera.schwarz(at)univie.ac.at.

Gerit Götzenbrucker (Assoz. Prof. Dr.), Department of Communication, University of Vienna, Währingerstraße 29, 1090 Vienna, Austria; Contact: gerit.goetzenbrucker(at)univie.ac. at. ORCID: https://orcid.org/oooo-0oo2-2626-8182

Fares Kayali (Univ.-Prof. Dr.), Centre for Teacher Education, University of Vienna, Porzellangasse 4, 1090 Vienna, Austria; Contact: fares.kayali(at)univie.ac.at. ORCID: https://orcid. org/0000-0002-0896-4715

Christiane Grill (Dr.), Mannheimer Zentrum für Europäische Sozialforschung, University Mannheim, 68131 Mannheim, Germany; Contact: christiane.grill(at)mzes.uni-mannheim. de. ORCID: https://orcid.org/oooo-0003-1334-4657

Peter Purgathofer (Ao. Univ.-Prof. Dr.), Human Computer Interaction Group, TU Wien, Argentinierstraße 8, 1040 Vienna, Austria; Contact: purg(at)igw.tuwien.ac.at. ORCID: https:// orcid.org/oooo-0001-5453-5631 


\title{
FULL PAPER
}

\section{Voxel generation \\ Raising awareness for informatics and society among high-school pupils through a game-design project}

\author{
Voxel Generation \\ Sensibilisierung für Informatik und Gesellschaft von Schülerlnnen \\ Höherer Schulen durch ein Game-Design-Projekt
}

\section{Vera Schwarz, Gerit Götzenbrucker, Fares Kayali, Christiane Grill \& Peter Purgathofer}

\begin{abstract}
Our research project was aimed at teaching high-school pupils game design skills and raising their awareness for the subject area "informatics and society." A project-basedteaching approach enabled us to incorporate social learning by having teams of pupils work on informatics-and-society topics and subsequently design their own games. The focus of this article is an online survey conducted twice, at the beginning and end of the pupils' project participation, showing if and how the participants' attitudes towards and awareness of informatics and society changed during this school year. We discuss the most important survey results, also in relation to studies on internet use of adolescents in the German-speaking countries. Additionally, an evaluation group discussion with the involved teachers provides expert validity. We found that our project-based and social-learning approach was successful in raising awareness for informatics and society as well as in teaching game design.
\end{abstract}

Keywords: Informatics and society; game design; social learning; adolescents; internet use.

Zusammenfassung: Unser Forschungsprojekt hatte das Ziel, SchülerInnen Höherer Schulen Game Design zu lehren und sie für das Thema „Informatik und Gesellschaft“ zu sensibilisieren. Durch Projektunterricht wurde soziales Lernen ermöglicht, da die SchülerInnen in Teams das Thema Informatik und Gesellschaft erarbeiteten und in der Folge ihre eigenen Spiele entwickelten. Der Fokus dieses Artikels liegt auf einer online-Umfrage, die wir zweimal durchführten - am Anfang und am Ende des Projekts aus SchülerInnensicht - und die zeigte, ob und wie sich Einstellungen und Sensibilisierung der TeilnehmerInnen gegenüber Informatik und Gesellschaft im Verlauf dieses Schuljahres änderten. Wir besprechen die wichtigsten Umfrage-Ergebnisse, auch in Verbindung mit Studien zur Internetnutzung von Jugendlichen in den deutschsprachigen Ländern. Darüber hinaus trägt eine EvaluationsGruppendiskussion der beteiligten LehrerInnen als ExpertInnen zur Validität der Ergebnisse bei. Wir stellten fest, dass der Schwerpunkt auf Projektunterricht und soziales Lernen zu einer erfolgreichen Sensibilisierung für Informatik und Gesellschaft sowie dem Erlernen von Game Design geführt hat.

Schlagwörter: Informatik und Gesellschaft; Game Design; soziales Lernen; Jugendliche; Internetnutzung. 
Acknowledgements: First and foremost, we would like to thank the pupils of the three participating classes who designed board games and digital games in the course of a school year, as well as their teachers Gerlinde Hipfl, Ruth Mateus-Berr, Andreas Schenk and Peter Suster. We would also like to thank the pupils of four more classes from the same schools who answered our online survey as a control group. Last but not least we would like to thank the Austrian Federal Ministry of Education, Science and Research (BMBWF) for funding our project within the "Sparkling Science" programme.

The title of this paper refers to the title of the digital game one of our project participant teams designed as part of this study.

\section{Introduction}

\subsection{Purpose of research}

Our research project "Sparkling Games" was funded within the "Sparkling Science" programme which focuses on scientists conducting their research together with pupils and teachers in schools. In our project, we had Viennese high-school pupils design games (digital games or board games) dealing with topics from the subject area "informatics and society." Our interests lay in triggering contemplation of informatics and society as well as in examining the suitability of game design itself as a teaching method - would the pupils be able to learn more about socio-technological issues by choosing a related topic and turning it into a learning game? Thus, the pupils' involvement was shaped as project-based learning, enabling us to approach from different perspectives and positions the final aim of having them design informatics-and-society games.

We hypothesize that project-based teaching (and specifically designing games as part thereof) is able to raise awareness for the subject area "informatics and society" among high-school pupils.

Although "informatics and society" is mentioned in the Austrian high-school curricula, it is not an area of great importance. The Austrian curricula in general - and even more so since the introduction of the centralised high-school exit exam ("Zentralmatura") in $2015^{1}$ - leave little space for covering anything that cannot easily be checked in an exam. Society and questions of social responsibility are mostly kept out of Austrian school education. Likewise, Koubek (2005) notes, concerning Germany, that the social context is mostly neglected in schools and informatics education primarily focuses on technical skills. In Austria, instead of enabling pupils to deepen their knowledge in topics they are interested in, the main emphasis is on imparting basic knowledge of a wide range of subjects to all pupils alike. Thus, only within the scope of project-based teaching - facilitated by the fact that we as external researchers intervened in the routine of school teaching - pupils became aware of informatics and society and the prevailing questions associated with the subject area.

1 Before, the teachers used to prepare the Matura exams individually for each of their classes. 


\subsection{Overview over the project "Sparkling Games"}

The key elements of the pupils' participation in our research project were:

- Participation in several workshops. All pupils attended three workshops facilitated by project team members: one at the beginning of the school year, introducing the project and also the subject area informatics and society; and two game design workshops, one of them in autumn (first semester), one of them in spring (second semester). On top of that, the pupils designing board games instead of digital games attended a fourth workshop, providing them with board game materials; this board game workshop was hosted by wienXtra-spielebox ${ }^{2}$, a city-funded board game library and youth work institute.

- Creation of an online database comprising learning games and opportunities for learning within "regular" games. For this task, the pupils had to play available digital games and assess them.

- Response to two online surveys dealing with informatics and society (at the beginning and end of the pupils' involvement). The survey results are presented in chapter 3 and discussed in chapter 5 of this article.

- Design of digital or board games in small teams.

- Attendance at two project gatherings for all participating pupils (of three different schools). In the first project gathering, the pupils were asked to give feedback on the other pupils' game proposals. In the second gathering, the pupils played everyone's finished board and digital games.

- Presentation of the games to other Viennese pupils and discussion of the design process at the Game City 2016, an annual trade show for digital games.

Two further articles covering the research project have already been published by the project team: one reflecting on the workshops, the two project gatherings and the games trade show (Kayali, Schwarz, Götzenbrucker, \& Purgathofer, 2017); a second dealing with the games database and the games created within the project by the pupils (Kayali, Schwarz, Purgathofer, \& Götzenbrucker, 2018).

The participating pupils attended three different Viennese schools with different characteristics: ${ }^{3}$

1) The GRG 21 Bertha von Suttner (Schulschiff) is an "Allgemeinbildende Höhere Schule" of the type "Gymnasium." It is a secondary academic school for general education, lasting eight years (lower cycle four years, upper cycle four years). Its exit exam is a general higher education entrance qualification.

2) The HAK/HAS 5 (Schule des BFI Wien) is a "Berufsbildende Mittlere Schule" as well as a "Berufsbildende Höhere Schule" of the type "Kaufmännische Schule." Our specific participating class has been an "Aufbaulehrgang," an add-on course enabling graduates of VET school (BMS) to finish VET college (BHS). The exit exam counts as general higher education entrance qualification and at the same time as professional commercial qualification. The parti-

2 https://www.wienxtra.at/spielebox/

3 Regarding the English terminology for Austrian schools, we refer to Institut für Bildungsforschung der Wirtschaft (2011). 
cular education path of youths attending a BMS first, followed by the add-on course, is a slightly slower way to acquire the BHS qualification: it takes six years instead of five for the upper cycle (while studying the same subjects). Thus, it is well-suited for working-class youths who are educationally disadvantaged due to their parents' low education and it is consequently mainly attended by proletarians.

3) The HTL 5 Spengergasse is a "Berufsbildende Höhere Schule" of the type "Höhere Lehranstalt für Informatik." It is a technical VET college for informatics and covers the upper cycle of secondary education, lasting five years. The exit exam counts as general higher education entrance qualification and at the same time as professional technical qualification.

\subsection{Structure of the article}

In this article, we first focus on relevant related research, specifically literature on the new digital divide and on certain myths regarding "digital natives" or "the net generation;" literature on internet use of youths in the German-speaking countries; as well as literature on informatics and society and on game-based; projectbased and social learning. Second, we elaborate on the most interesting results of an online survey we conducted among the participating pupils from three different schools; the online survey was aimed at learning about the participating pupils' knowledge on and attitudes towards informatics and society as well as at raising their awareness for the subject area. Third, we present the findings of a group discussion we held with the participating teachers on the success and impacts of the project. Last, we discuss the results of the online survey and the teacher discussion. In short, we found that we managed to raise the pupils' awareness for informatics and society, and that our project-based-learning approach was effective, in large part because of social and peer learning.

\section{Related research}

\section{1 "Digital natives" and the new digital divide}

Although some authors have ascribed certain specific characteristics to those born from (roughly) 1980 onward - frequently called "net generation," "generation Y," "millennials" or "digital natives" - on closer look, the main difference to previous generations is the availability of new digital media. However, this availability alone does not account for a substantial change in character traits. As Schulmeister $(2010 ; 2009)$ argues, recreational activities have in fact not changed very much during the past decades. Spending time with friends or family, and TV, music or sports are still the most favourite activities of today's youth. Additionally, a lot of the time spent in front of a computer or with a cellphone is used for communicating with friends - a feature that was plainly not available to youths $25+$ years ago. Also, the digital divide (access to new technologies) and new digital divide (user expertise/digital literacy) have to be taken into consideration. When incorporating both digital divides, it becomes clear that children and youths now- 
adays are in no way a homogeneous group but differ significantly not only with regard to their access to new media but as well with regard to their competencies and media literacy.

Ballano, Uribe, and Munté-Ramos (2014) conducted a qualitative study among Spanish high-school pupils, teachers and parents in order to find out more about the generational digital gap. They describe differences between internet usage habits of youths and adults but find that these differences cannot be explained by generation. Rather, youths and adults alike show different levels of skills and different perceptions of their roles as internet users, owing to different factors (p. 153): "The digital divide is a very complex, dynamic reality in constant evolution.” Also, Park (2015) re-examined data from a US survey of 800 teenagers and their parents, where he found much more connection between the families' social statuses and the teenagers' mobile skills than between access to mobile services and mobile skills. This means, access to mobile services alone does not shape the youths' mobile use, in fact their use is also shaped by class and race. Already in 2009, Zillien and Hargittai analysed the relation between internet users' social positions and their uses of the web. They found:

Overall what this tells us about the broader discussion surrounding the digital divide is that digital inequalities are not only a temporary social phenomenon that will disappear once high-quality equipment and comfort with the Internet become more widespread. Even if status inequalities concerning technical equipment and digital experience were to decline, status-based differences in Internet usage would likely persist. (Zillien \& Hargittai, 2009, p. 288)

They further emphasize that internet use is determined by various factors, among which social status is an important one.

\subsection{Internet use of adolescents in the German-speaking countries}

In a meta-study, Klingler, Feierabend, and Turecek (2015) address the internet and media use of German adolescents and young adults from 2000 until 2014. They focus on time spent using media, motivations for media use, devices and the influence of social background. Regarding internet use, youths in the year 2000 and youths in the year 2014 constitute two different generations. Thus, media exposure during their formative years varies greatly. Adolescents' media use depends on a variety of factors, such as availability or technical requirements and to a great extent on the possibilities and specific situations of their daily lives. These range from distinct social contexts to external factors like education or (un)employment (p. 199). The consumption of radio and TV has only seen a slight decline during the years 2000 to 2014. Internet use, however, has reached $100 \%$ in 2014 for at least occasional use (compared to just $49 \%$ in 2000) and $91 \%$ for daily use among the 14- to 19-year-olds (p. 201, Tab. 2). Internet use among adolescents differs significantly from the rest of the population. Communicating is in terms of time spent - the number-one purpose of using the internet for people between 14 and 29 years of age. As the internet has reached a high level of relevance in daily life, accessing the web by means of a smartphone has by 2014 reached the point of complete dominance ( $81 \%$ use a smartphone to go online). 
Social background is accountable for only slight differences - generally, radio, TV and the internet are equally relevant for youths from all milieus. Specifically, this also means that the implication of higher education resulting in less media use is incorrect (pp. 205-206). It is not possible any more to imagine youths' daily lives without the internet, as personal online communication takes on an important role; also, the internet is used to consume all other media. The question remains if differences in media use between youths and adults are due to the age difference or if today's adolescents can be seen as pioneers for completely new ways of dealing with media. The answer will only become clear in hindsight (pp. 208-209).

The following section outlines several quantitative studies on the internet use of German and Austrian adolescents:

- The Austrian organisation "saferinternet.at" collected data on social media use by Austrian youths aged 11 to 17 for their "Jugend-Internet-Monitor 2017." The study also presents numbers regarding gender. (saferinternet.at, 2017)

- The "Oberösterreichische Jugend-Medien-Studie" (Upper Austrian youth media study) is conducted biennially; in 2017 for the fifth time. It builds on interviews with teenagers (ages 11 to 18), parents of children aged 11 to 18, as well as lower secondary school teachers from Upper Austria, and deals with the youths' media use and media habits. (Education Group [EduGroup], 2017)

- The annual German "JIM-Studie 2018" (Youth, information, media study 2018) uses a sample of 1,200 interviewees which is representative of ca. 6.4 million German youths (12 to 19 years of age). (Medienpädagogischer Forschungsverbund Südwest [mpfs], 2018)

- The "ARD/ZDF-Onlinestudie" is conducted annually by the German public broadcasting companies ARD and ZDF; it features representative data on internet use in Germany. In March and April 2017, more than 2,000 Germans over 14 years of age were questioned. (ARD/ZDF Projektgruppe Multimedia [ARD/ZDF], 2017)

- "Generation What" was a large online survey, conducted in 2016 by members of the European Broadcasting Union in 15 different European countries. (Generation What, 2016)

- The "Shell Jugendstudie 2015" is another youth study from Germany, surveying a representative sample of 2,558 12- to 25 -year-olds. (Shell Deutschland [Shell], 2015)

- The "DIVSI U25-Studie" on children, teenagers and young adults was published in 2014 by the "Deutsches Institut für Vertrauen und Sicherheit im Internet" (German institute for trust and security on the internet). The survey is based on computer-assisted personal interviews with roughly 1,500 children, youths and young adults in Germany, aged 9 to 24 years. The study's goal was to broadly illustrate the digital environments of young people. Thus, the researched topics comprised media use, trust and security online, and attitudes towards privacy and identity online as well as towards exchanging and sharing media. (Deutsches Institut für Vertrauen und Sicherheit im Internet [DIVSI], 2014) 
- "EU Kids Online II" was a study on risk and safety online, conducted in the year 2010 among more than 25,000 children and youths (9 to 16 years of age) as well as their parents in 25 countries across Europe. (Forschungsverbund EU Kids Online [EU Kids], 2011)

Computers and smartphones are an important part of adolescents' everyday lives. Internet access of youths in Germany and Austria is as wide-spread as $99 \%$ (ARD/ZDF, 2017; EduGroup, 2017; mpfs, 2018; Shell, 2015; EU Kids, 2011). 94 to $97 \%$ of teenagers own a smartphone with internet access, and smartphones are the most common way of accessing the internet; other - less used - devices are: (laptop) computers, tablets, TV sets, gaming consoles (EduGroup, 2017; mpfs, 2018). While internet access itself is thus clearly not any more determined by social position, the range and diversity of devices enabling internet access still is: while $47 \%$ of youths from high-status families use three or more devices to go online, only $17 \%$ of youths from low-status families have that many devices available (Shell, 2015, p. 18). According to the survey Generation What (2016), $53 \%$ of the Austrian youths (16 to 17 years of age) "could not be happy without Internet," whereas only $47 \%$ think they could be. However, in Germany even $56 \%$ think they "could not be happy without Internet." In comparison, when asked if they could be happy without a mobile phone, $51 \%$ of the 16 - to 17 -yearold Austrians answer "yes," 49 \% answer "no." In Germany, 55 \% state that they could be happy without a mobile phone, $45 \%$ think they could not. According to the ARD/ZDF-Onlinestudie, teenagers and young adults use their smartphone more often in public spaces than people over the age of 30 (ARD/ZDF, 2017). As of 2017, WhatsApp, YouTube, Instagram and Snapchat are the youths' favourite applications, while Facebook is on the decline (EduGroup, 2017; mpfs, 2018; saferinternet.at, 2017); in 2018, Netflix has experienced a notable rise in popularity, placing the platform ahead of Snapchat (mpfs, 2018).

Several motivations for internet use are mentioned in the studies: communication; information (including education, learning); entertainment (including media consumption, gaming); creativity (ARD/ZDF, 2017; EduGroup, 2017; mpfs, 2018; Shell, 2015; EU Kids, 2011). German teenagers use the internet from 214 minutes (on weekdays; mpfs, 2018) up to 274 minutes (ARD/ZDF, 2017) per day. Already in 2015, the Shell Jugendstudie found that, on average, teenagers were online for 18.4 hours a week. While the Shell Jugendstudie (2015) has identified five main internet user groups - information seekers, media consumers, digital citizens, occasional users and interactive self-portrayers (pp. 19-20) -, the DIVSI U25-Studie (2014) grouped the respondents into seven milieus (pp. 26-28). The DIVSI U25 also states that the level of education (which children and their parents frequently have in common) is connected to the way the young people use media in general, and specifically digital media. The children, youths and young adults with a low level of education show less confidence regarding their online knowledge and skills and also a less diverse use of the internet. Also, females show less confidence regarding their online knowledge and skills than males (DIVSI, 2014). 
Apart from using the internet (including use for consumption of different media), today's teenagers like to spend their spare time with friends (favourite activity!), their families, do sports or be creative. They do even still read classic, paper-made books (EduGroup, 2017; mpfs, 2018; Shell, 2015). The majority of youths want to participate in the social space internet because not participating means exclusion from important parts of their peers' everyday lives (Shell, 2015). However, the DIVSI study shows that children, youths and young adults do distinguish between "real" friends and online friends or acquaintances. Even if they have added a lot of contacts on social network platforms, they are aware that those are not actual friends (DIVSI, 2014). Nevertheless, the risk that children and youths between nine and sixteen face most likely when using the internet, is communicating with strangers. $30 \%$ of the respondents have at least once communicated online with people they had not previously met in person (EU Kids, 2011).

According to the Shell Jugendstudie (2015), critical awareness of the internet, its privacy issues, and its big actors is rather high. The adolescents question what is happening with the information they provide and the data they create through their use of the internet. Although $72 \%$ agree that they are careful with their private data when online, the impact of this notion on their real actions is unknown. In this regard, the DIVSI U25 (2014), comes to the conclusion that the study participants mainly feel the need to protect their personal information (including chat messages etc.) from their "real-world" circles, as opposed to the need to protect their privacy from data collection by big companies and/or state surveillance. Also, they tend not to spend too much time adjusting the privacy settings of the social media they use. EU Kids Online II (2011) infers that the intensity of internet use shows a positive relation to internet literacy and knowledge about safety measures. In addition, while a more frequent internet use exposes children and youths to a higher number of risks overall, it also results in more opportunities for the young users. Among the 11- to 16-year-old respondents, almost two thirds state to know how to block unwanted messages, and how to ask for support online; around half are able to manage privacy settings for a social network account, to do a qualitative comparison of two websites, and to block spam e-mails. The confrontation with risks online is not necessarily perceived as a negative experience by the young users. Only $12 \%$ of the respondents state that experiences online made them feel uncomfortable or hurt them $(9 \%$ among the 9- and 10-year-olds). The Oberösterreichische Jugend-Medien-Studie (EduGroup, 2017) further supports this assumption: in spite of the intensive use, unpleasant online experiences seem to happen rarely (the interviewees mainly mentioned viruses and annoying ads). The internet's dangers and risks are addressed in school, and by parents (particularly between children's ages of 11 and 14). The teenagers feel they are well-informed regarding the internet and view themselves as their families' internet experts. According to DIVSI U25, the survey participants do not perceive their parents and/or teachers as suitable advisors regarding internet use in general as well as risks and dangers of the internet use in particular because they believe they are more internet literate themselves than (most) grown-ups (DIVSI, 2014). 


\subsection{Game-based learning and informatics \& society 4}

As Brown and Vaughan (2009, p. 212) put it: "Play is exploration, which means that you will be going places where you haven't been before.” They propose a view of games as possibility spaces, which allow exploring activities without fearing the consequences of your actions. Such safe-to-fail game environments are important for learning and can enable children to face the consequences of their actions in a playful and explorative way. We chose a game-design as well as game-based approach to teaching the rather abstract subject area informatics and society in high schools: in addition to designing games of their own, the pupils also played different games throughout the project. Baumgartner, Laske, and Welte (2000) distinguish between behaviourist, cognitivist and constructivist learning models. In learning games, especially the constructivist approach is relevant for working out possible solutions and handling complex situations. Squire (2006) highlights three areas of learning where game-based approaches are important: collaborative learning, learning through failure, and personalized learning. Playful and participative approaches are promising concepts for use in game-based learning. Game design is in itself participative, playful, and - when done in teams - a collaborative effort. The games designed by the pupils were to be learning games. In the workshops, we shared our learning games expertise with the participants.

In 1970, Abt provided the first definition of serious games as games designed for a primary purpose other than pure entertainment. Michael and Chen (2006) later similarly defined serious games as "games that do not have entertainment, enjoyment or fun as their primary purpose” (p. 21) and gave a series of application areas: military games, government games, educational games, corporate games, healthcare games, and political, religious and art games. Klimmt (2009) deals with the potentials of serious games in relation to fostering social change. Studies like de Freitas' (2006) "Learning in Immersive worlds. A review of gamebased learning," Wagner and Mitgutsch' (2008) "Didaktische Szenarien des Digital Game Based Learning," and Fromme, Jörissen, and Unger's (2008) “Bildungspotenziale digitaler Spiele und Spielkulturen" provide an overview of existing commercial games used in the classroom as well as games designed specifically for the classroom. Among the benefits of game-based learning are increased motivation (Garris, Ahlers, \& Driskell, 2002; Papastergiou, 2009), intrinsic motivation (Deci \& Ryan, 2012; Malone \& Lepper, 1987), enjoyment of learning (Koster, 2004; Lazzaro, 2008), and immersion into an authentic (Galarneau, 2005; Squire, 2006) and encouraging (Kiili, de Freitas, Arnab, \& Lainema, 2012) learning experience. Pupils can experiment without having to think about consequences beforehand. Errors are not punished, but can lead to enhanced understanding (Juul, 2013; Squire \& Jenkins, 2003). For games, a so-called "magic circle" exists: a temporary, locally limited protective framework within which explorative learning experiences become possible (Huizinga, 1955; Salen \& Zim-

4 This section is based on a previously published article by the project team: Kayali, Schwarz, Götzenbrucker, \& Purgathofer, 2016. 
merman, 2004). A critical view on game-based learning reveals that in-game progress does not necessarily equal successful learning (Linderoth, 2012). It has also been shown that players in fact only improve in the exact area that is being trained - with the possibility of a slightly different task wording causing problems (Green \& Bavelier, 2006).

There are several examples of existing learning games dealing with informatics and society. Valcke, De Wever, Van Keer, and Schellens (2011) give an overview of studies on internet learning games. "Internet Hero" follows several of J. P. Gee's (2007) learning principles in familiarizing children aged 8 to 12 with the internet (Kayali et al., 2014). Juhari \& Mat Zin's (2013) "Cyberworld Adventure" and "Net-Detectives" (Wishart, Oades, \& Morris, 2007) are games teaching safe internet use to 9- to 12-year-olds. "Anti-Phishing Phil" (Sheng et al., 2007) is an online game explaining protection from phishing attacks. In the three last-mentioned studies, positive effects on the participating children's and adolescents' internet knowledge and skills are reported. The game "SimSafety" (Kalaitzis, Valeontis, Delis, \& Fountana, 2010) also deals with internet security; Xenos, Papaloukas, and Kostaras (2010) present a study on an early version of the game.

We drew on and expanded the above-mentioned informatics-and-society-related topics ${ }^{5}$ to compile an exemplary list for use in our workshops with the participating pupils:

- accessibility of technologies

- copyright

- corporate surveillance

- cyberbullying

- cybercrime

- data security of banks, insurance companies etc.

- digital divide

- digital rights management (restrictions on music, movies, e-books ...)

- ethical issues

- extortion malware

- hacking and critical systems (nuclear power plants, hospitals etc.)

- identity theft

- lacking diversity in IT (fewer women, immigrants ...)

- loss of jobs due to automation

- privacy/voluntary disclosure of personal information

- reliance on/dependence of technologies

- state surveillance

- site blocking and internet censorship

5 I.a., we consulted the official computer science curricula as issued by the ministry of education. 


\subsection{Project-based and social learning}

In Austria, project-based learning first appeared in schools in the 1980s, introduced by teachers who were looking for alternatives to traditional school teaching and learning (Fridrich, 1994; for Germany, cf. Emer, 2013). Since then, project-based learning has been present in Austrian schools, yet it is not too common. Whether project-based learning is applied, is mostly an individual decision of single teachers.

Schumacher and Rengstorf (2013) analyse German- and English-language empirical studies on project-based learning. They conclude that project-based learning is promising but also requires considerable expertise of the teachers. A number of principles important for and goals of project-based learning have been identified by various authors (Gudjons, 2014; Hänsel, 1997; Krajcik \& Shin, 2014). For example, projects have to be connected with pupils' social practices and with society; usually, a product of some kind is the final result, and it is publicly presented; pupils work quite autonomously in small groups and have a say in what the product they are creating will be like (see also Rengstorf \& Schumacher, 2013; Thomas, 2000; Traub, 2012). Also, project-based learning and social learning - which we go on to discuss next - are closely connected.

Various theories of social learning exist side by side; however, the project team's approach is based on Ruth C. Cohn's "theme-centered interaction (TCI)." This concept is influenced by psychoanalysis, group therapy, and humanistic psychology. It aims to foster autonomy and empowerment of learning group members by balancing different factors relevant to group processes: the "I" (i.e. the individuals comprising the group), the "We" (the group as group), the "It" (the theme), and the "Globe" (the surroundings, the environment of the learning situation) (Cohn, 1975; Schneider-Landolf, Spielmann, \& Zitterbarth, 2017).

Social learning in classrooms (Goldenbaum, 2012, pp. 15-68) happens unintentionally but can also be intentionally emphasized and guided by teachers. Social learning means dealing with social circumstances, society and one's role within (cf. project-based learning); it means an education in better understanding and eventually adopting social norms. Thus, social learning is also closely linked to the acquisition of social skills (often called "soft skills") by way of being part of a socially relevant (peer) group. Social learning ideally contributes to youths' personal development, supporting them in becoming responsible, critically-thinking adults. This is discussed, for example, by Popp (2009), by Steins \& Haep (2014) or by Goldenbaum (2012). Our project "Sparkling Games" combined explicit consideration of society-related aspects of information technology with a peergroup learning approach. When facilitating the workshops and project gatherings, the team used TCI as a method (cf. Schneider-Landolf et al., 2017) - i.a., we encouraged communication and social interaction, and we worked towards creating a pleasant, respectful atmosphere (cf. Popp, 2009; Steins \& Haep, 2014).

\subsection{Summary}

In this article, so far we have outlined that:

- $\quad$ society is rarely addressed in schools, and much less informatics \& society; 
- games and game design are suited to facilitate learning;

- project-based teaching facilitates learning;

- youths today have access to an unprecedented variety of media (above all the internet), however, compared to previous generations, most of their interests, practices and also challenges remain unchanged.

In our project, we intended to make adolescents aware of informatics-and-society topics and to teach them game design. We chose to use a project-based-learning format, including a social-learning approach in our workshops. And we wanted to find out more about our project participants with regard to internet use and informatics and society. Thus, we formed the hypothesis that project-based teaching (and specifically designing games as part thereof) is able to raise awareness for the subject area "informatics and society" among high-school pupils.

In order to find out more about the young project participants, in addition to our hands-on approach consisting of workshops and game design in small groups, we also decided to conduct an online survey (see below, chapter 3 ). The underlying research questions were: 1) How do the pupils view different aspects of informatics and society? 2) Are their views, attitudes and practices in line with youths in Austria and Germany as researched in various empirical studies? Furthermore, the survey was in itself a factor in raising awareness towards informatics and society, as it served to introduce certain informatics-and-society-related topics (complementary to the workshops).

\section{Online survey}

\subsection{Method and data}

In our study's quasi-experimental pretest-posttest design, one of the pupils' assignments was answering an online survey dealing with informatics-and-society topics. The survey was, on the one hand, designed to provide the project team with insight into the youths' knowledge on and attitudes towards informatics and society as well as into their internet usage habits. On the other hand, the survey was designed to raise the youths' awareness for socio-technological issues. We mainly used interval scales (4 and 6 range) and item rankings on ordinal scales. The questions were largely based on the literature discussed above (chapter 2). Some items were directly derived from the empirical studies, like: time spent online, internet expertise, and used applications; others were inspired by the empirical studies as well as by the subject area informatics and society: risks online, privacy issues, safety measures, gender differences, cyberbullying, and reliability of information online.

The first set of the survey was conducted at the beginning of the project and comprised 42 questions. The second set was conducted after the pupils had finished their task of designing a learning game themselves (i.e. at the end of the project from the pupils' point of view) and consisted of 28 questions, all of which had already been asked in the first set. Thus, the survey shows if (and in what direction) the participating pupils' attitudes and awareness have changed during the 
course of the project. Table 1 below illustrates the sample's gender and age distribution by schools.

Table 1. Survey participants' gender and age distribution by school

\begin{tabular}{lcccccccc}
$\begin{array}{l}\text { Overview: } \\
\text { survey }\end{array}$ & \multicolumn{2}{c}{ GRG 21} & \multicolumn{2}{c}{ HAK 5 } & \multicolumn{2}{c}{ HTL 5 } & \multicolumn{2}{c}{ total } \\
participants & set 1 & set 2 & set 1 & set 2 & set 1 & set 2 & set 1 & set 2 \\
male & 5 & 1 & 7 & 5 & 18 & 16 & 30 & 22 \\
female & 14 & 13 & 12 & 11 & 1 & 1 & 27 & 25 \\
total & 19 & 14 & 19 & 16 & 19 & 17 & 57 & 47 \\
ages (most & $14-15$ & $14-16$ & $18-22$ & $18-23$ & $17-19$ & $17-19$ & & \\
prevalent) & $(14)$ & $(15)$ & $(19+20)$ & $(20)$ & $(18)$ & $(19)$ & &
\end{tabular}

The pupils' gender and age distribution were predetermined by their school-class affiliation, which was largely determined by feasibility - we co-operated with teachers at three different schools and they each chose one of their classes to participate in the project. The option of consciously choosing project participants (and the control group) according to specific criteria simply did not exist. Particularly, in the HTL class there was only one girl while in the GRG class almost three quarters and in the HAK class almost two thirds were girls. Due to our project's schedule, the pupils were asked to answer the second survey at the very end of the school year; unfortunately, this resulted in a slight drop in response rates. Most notably, five less pupils of the GRG class answered the second survey, interestingly four of which were boys (out of only five boys in this class). The HAK class' responses dropped by three and the HTL class' by two.

There was a control group for the survey, consisting of school classes of the same type and grade as the project participants' (namely the pupils designing learning games). The control-group pupils answered the same survey questions at the same time as the project participants. We intended to detect whether the yearlong involvement of the participating pupils with project-based learning confronting them with informatics-and-society topics when designing their games would result in them learning more about informatics and society than regular pupils. However, in general there were no statistically significant differences between the participants and the control group. Still, there is evidence by tendency that the project participants' awareness for socio-technological issues was raised. Therefore, below we will discuss in a quantitative analysis the project participants' most relevant answers regarding the presence of significant differences or differences by tendency, while comparing sets 1 and 2, gender, age and school type (see table 1 above for gender and age distribution by school). Due to the similarities, we neglect the control group in this analysis.

Several factors might have contributed to the lack of differences between the control and the project group - i.e. according to our data, awareness for informatics and society was also raised within the control group. Among those factors are some immanent to the research project: first, the survey itself had the side effect of raising awareness for informatics and society - which was in fact intended with regard to the project group; second, the control groups were taught by the 
same teachers as the project groups - the teachers might unwittingly have influenced the control-group pupils by discussing informatics and society more explicitly during the project year than usually; third, we cannot rule out that the project participants themselves talked to pupils in the control group about the project's topic. Pretest-posttest designs always bear the danger of influencing the posttest through the pretest questions. Also, our intervention was not an experiment under controlled conditions but was embedded in everyday school life and thus various influencing factors might not even have been obvious to us, the outsiders.

In the following sections, the survey results are presented and discussed. Further discussion, also in regard to related research, see chapter 5 of this article.

\subsection{Time spent online}

In the survey, we asked the participants how much time they spent online per week. ${ }^{6}$ There is no statistically significant difference between the time boys and girls spend online $(t(55)=1.50, p<.139)$. By schools, in the first survey the pupils of the HTL spent the most time online (16 to 30 hours a week on average), the pupils of the HAK the least (up to 15 hours a week on average). This did not change in the second survey. The school type HTL comes with a focus on informatics, which the pupils voluntarily chose, so they are most likely to spend more of their spare time as well as their school-related time online. The HAK pupils, on the other hand, comprise the oldest part of our sample. However, not only are most of them already adults, due to their specific school career they are also most likely to be from proletarian families ${ }^{7}$. These factors suitably explain the slight differences in time spent online.

We also asked if they considered their internet use "too much," "appropriate" or "too little." without showing a significant difference by school $(\mathrm{F}(2,113)=2.06, p=.132)$. Nevertheless, there was a significant difference by gender $(\mathrm{F}(1,98)=4.37, p<.05)$ in the first survey set: girls more often stated that they used the internet "too much." In the second set, this difference has disappeared. Even though the girls do not spend more time online than the boys, they are more likely to think their use is "too much." Due to social expectations towards girls, they might be more critical of themselves and how they spend their time. The fact that the girls' answers do not differ from the boys' ones in the second survey any more, may be a result of raised awareness through their project participation.

6 „Wie viele Stunden in der Woche bist du durchschnittlich im Internet aktiv? - gar nicht - bis zu 15 Stunden (maximal ca. 2 Stunden pro Tag) - 16 bis 30 Stunden (ca. 2,5 bis 4 Stunden pro Tag) - 31 bis 50 Stunden (ca. 4,5 bis 7 Stunden pro Tag) - mehr als 50 Stunden (mehr als ca. 7 Stunden pro Tag)“

7 See our explanation of specifics regarding the three participating schools in section 1.2.

8 „Ich finde, ich benutze das Internet - zu viel - gerade richtig - zu wenig“ 


\subsection{Internet and application/platform expertise}

We asked them how familiar they felt with the internet: "very familiar," "familiar," "a little familiar," "less familiar." 9 In the first set, on average most pupils answered "very familiar" or "familiar," without any gender or school differences showing. In the second set, a statistically significant difference by school $(F(2,102)$ $=3.62, p<.05)$ and gender $(\mathrm{F}(1,98)=6.51, p<0.05)$ is showing: the HTL pupils assess their familiarity higher than the pupils attending the other two schools. Also, the boys assess their familiarity higher than the girls. The change in results by school might be due to participants' more realistic view on their internet expertise: in accordance with their school's emphasis on informatics, the HTL pupils are indeed likely to have the highest internet expertise in our sample. The gender difference only showing in the second survey set is unfortunate; most likely it is rather a consequence of sexism and gender stereotypes than a reflection of actual knowledge or expertise.

In the first survey set, subsequently we asked them how familiar they were with these (social media) platforms or applications: Facebook, Instagram, Tumblr, Twitter, Snapchat, YouTube, Google, WhatsApp. ${ }^{10}$ According to their answers, they are most familiar with WhatsApp, followed by YouTube and Google, whereas they are least familiar with Tumblr, followed by Twitter and Snapchat. They could also choose "I do not use it" as an answer, which shows that Tumblr is also least used by them, followed by Twitter and Snapchat.

\subsection{Distressing internet content}

Another set of questions in our first survey dealt with internet content they came across and considered not to be age-appropriate. Those who answered "yes" where asked for an example and, at last, if they thought their access to age-inappropriate content was a problem: ${ }^{11} 35$ stated they had come across age-inappropriate content, 24 of them male and 11 female; of those, 10 considered it problematic ( 4 male, 6 female). 13 (12 males and 1 female) also provided an example. Eleven answers concerned sexually explicit or porn content; one answer reads "porn, violence;" one answer reads "facebook videos."

Interestingly, much more males than females admit to having seen age-inappropriate content online. As girls are much more likely to consider access to age-inappropriate content problematic, they might approach internet surfing more cautiously and are thus less confronted with the things they do not think they should see. The oldest pupils of the sample, those attending the HAK, consequently saw the least age-inappropriate content, while the HTL pupils saw the most - unsur-

9 "Mit dem WWW kenne ich mich aus - sehr gut - gut - etwas - weniger gut“

10 „Ich kenne mich aus mit - Facebook - Instagram - Tumblr - Twitter - Snapchat - YouTube Google - WhatsApp; sehr gut - gut - etwas - weniger gut - verwende ich nicht"

11 „Ich habe im WWW bereits Zugriff auf Inhalte gehabt, die meiner Ansicht nach für mein Alter nicht geeignet waren“ - „Wenn du möchtest, nenne bitte ein Beispiel“ - „Ich habe im WWW bereits Zugriff auf Inhalte gehabt, die meiner Ansicht nach für mein Alter nicht geeignet waren und ich sehe das als problematisch an" 
prisingly, as they use their computers and the internet differently and are more rooted in nerd culture.

A second, related, set of questions dealt with "things they had rather not seen." Again, we also asked for an example. ${ }^{12}$ This time, 39 answered "yes" (22 male, 17 female) and 15 provided an example (11 male, 4 female). Among the examples for things they had rather not seen were 6 mentions of violence (right up to gore) and 8 mentions of deviant sexual content (mainly "shock videos"). Again, more boys than girls stated they came across things they had rather not seen, and more boys cited examples, although the difference is much smaller than with the question before. Once more, too, the HTL pupils were most likely to see things they had rather not seen online - nerd culture makes them come across things online less-skilled users do not. So-called "geek cultures" (Tocci, 2009) can be described as rather male-driven, "white and nerdy" (Kendall, 2011).

\subsection{The internet as a source for news and information}

Furthermore we asked them how frequently they used the internet to research information they would not ask anyone about; ${ }^{13}$ how frequently they used the internet to read/watch news; ${ }^{14}$ and if they had already learned something when using the internet. ${ }^{15}$ In our first survey set, girls used the internet significantly less frequently than boys for both, researching information they could not ask anyone about $(\mathrm{F}(1,97)=17.20, p<.001)$ and following the news $(\mathrm{F}(1,96)=5.12$, $p<.05)$. In the second set, however, the gender difference regarding following the news disappeared. The fact that boys are more likely to use the internet as a source for news and information, might be due to the different way male and female adolescents communicate and form friendships. Girls form closer friendships and talk more about personal things with their friends, so they probably rely more on the personal exchange of news and information while boys focus more on shared activities with their friends. Hargittai, Fullerton, MenchenTrevino, and Thomas (2010) point out, too, that people tend to use the same "offline" networks they generally rely on in life to gather information (p. 472).

The vast majority of the survey participants confirmed that they had already learned something when using the internet. In both survey sets, a gender difference is showing: boys were more likely to have learned something. Again, this may be due to different communication and friendship styles of males and females. Those who stated they had learned something on the internet, had to give an example (open question). In the first survey, there were 49 comments. The most common examples included computer skills and knowledge (15 mentions) as well as school-related or school-like skills and knowledge (14 mentions); some

12 „Ich habe im WWW bereits Dinge gesehen, die ich lieber nicht gesehen hätte“ - „Wenn du möchtest, nenne bitte ein Beispiel“"

13 „Im WWW suche ich nach Informationen, nach denen ich sonst nicht fragen würde - häufig manchmal - selten - nie“

14 „Ich nutze das WWW um aktuelle News zu lesen/schauen - (fast) täglich - 2-3 Mal pro Woche seltener - nie“

15 „Ich habe im WWW bereits Neues gelernt“ - „Nenne bitte ein Beispiel“ 
of the participants mentioned very specific topics or knowledge that does not fit in the above categories ( 7 mentions) or leisure activities ( 3 mentions). In the second survey, there were 37 comments. Again, computer skills and knowledge (8 mentions), school-related and school-like skills and knowledge (8 mentions), and specific topics and knowledge (7 mentions) were the most common answers.

\subsection{Computer aptitude of males/females}

The survey participants were asked to assess the computer aptitude of - first males and - second - females on a scale of 1 to $6 .{ }^{16}$ The results show a statistically significant gender difference $(\mathrm{F}(1,98)=21.37, p<.001)$. Male participants assessed the aptitude of males as well as the aptitude of females higher than female participants. However, both genders attributed higher aptitude to males than to females: in the second survey set, on average males were assigned a value of 5.7 by male and a value of 4.39 by female survey participants, whereas females on average were assigned a value of 5 by male and a value of 3.96 by female survey participants. Interestingly, the participating girls view people - regardless of gender - as less computer apt than the participating boys. This might reflect the fact that computers play a smaller part in girls' lives than in boys' lives. Also, in comparison to the boys, the girls think of themselves as a little more computer apt: the difference between boys' and girls' aptitudes is 1.31 when looking at the answers by males and only 1.04 when looking at the answers by females. However, these results are likely distorted by the fact that the HTL class - which was also the one where the most computer aptitude could be expected due to the school's ICT focus - consisted of 18 boys and only one girl, while the other classes consisted of more girls than boys.

\subsection{Passwords and security}

When asked if they considered the use of secure passwords "very important," "important," "less important" or "not important at all," 17 in the first survey set the HAK pupils considered secure passwords most important in comparison to the HTL and GRG pupils. However, in the second survey set no statistically significant difference by school was found $(\mathrm{F}(2,40)=1.21, p=308)$ - they all considered the use of secure passwords "very important." This change is likely an effect of our project and the pupils' involvement in informatics and society. Also, by tendency girls considered secure passwords more important than boys, probably because they are more eager to ensure their privacy in a society employing double standards towards behaviour expected from males and females, specifically on the misogynist internet.

16 „Auf einer Skala von 1 bis 6, wie gut sind Männer/Buben für Informatik/Computer geeignet? 1 = gar nicht geeignet; 6 = sehr gut geeignet “; „Auf einer Skala von 1 bis 6 , wie gut sind Frauen/ Mädchen für Informatik/Computer geeignet? - 1 = gar nicht geeignet; $6=$ sehr gut geeignet“"

17 „Ein sicheres Passwort ist mir - sehr wichtig - wichtig - weniger wichtig - ganz unwichtig“ 
Different examples of double standards are discussed by Foschi (2000 - competence), Fugère, Escoto, Cousins, Riggs, and Haerich (2008 - sexuality), and de Visser and McDonnell (2012 - alcohol use). Regarding the internet, Drakett, Rickett, Day, and Milnes (2018) exemplary illustrate certain internet memes' potential for the exclusion and policing of women from/in online spaces, as well as the memes' role in the construction of gendered identities:

We suggest that, whilst the image macros analysed reproduce many well-worn discourses concerning gender, they mobilise these discourses in a new medium in order for heteronormative, masculinised identities to claim rightful ownership of this medium and the spaces in which it presents itself. (p. 122)

Also, according to Biber, Doverspike, Baznik, Cober, and Ritter (2002) women perceive misogynist comments and statements online as more harassing than in face-to-face settings (p. 38).

Almost $90 \%$ of the survey participants in both survey sets stated that their passwords were at least 7 characters long. ${ }^{18}$ Additionally, in the second set $51 \%$ claimed not to use the same password everywhere, while $7 \%$ said they did and $42 \%$ answered "for some services only." ${ }^{19}$ However, in the first set, $40 \%$ said they did not use the same password everywhere, $11 \%$ answered they did and $49 \%$ claimed they used the same password "for some services only." This means, in the second survey set they were $11 \%$ more likely to not use the same password anywhere, $4 \%$ less likely to use the same password everywhere and $7 \%$ less likely to use the same password for at least some services. This may be due to their engagement in informatics-and-society topics throughout their project participation.

\subsection{Anonymity online and privacy}

Another question read: "The anonymity on the internet results in ..." Selecting multiple answers was possible: "freedom of expression"; "establishing contacts prejudice-free"; "insult/abuse"; "dishonesty/deception"; "other, namely:" (open answer); "Anonymity on the internet does not exist."; "I do not know." 20

In both sets, most survey participants chose "freedom of expression" (set 1: $61 \%$, set 2: $53 \%$ ). "Dishonesty/deception" was chosen by $40 \%$ of the participants in both sets. However, in set 1 it was the third-most chosen answer, while in set 2 it was the second-most chosen answer. "Insult/abuse" was the second-most chosen answer in set $1(44 \%)$ and the third-most chosen answer in set $2(36 \%)$. "Establishing contacts prejudice-free" accumulated $37 \%$ in the first set and $25.5 \%$ in the second set. "Anonymity on the internet does not exist." was chosen by $19 \%$ and $17 \%$, respectively. As can be seen, there were fewer positive an-

18 „Mein Passwort hat/meine Passwörter haben (meist) eine Länge von - bis zu 6 Zeichen - 7 bis 12 Zeichen - über 12 Zeichen “

19 „Ich verwende überall dasselbe Passwort - ja - nein - nur für manche Dienste“

20 „Anonymität im WWW führt zu (Mehrere Antworten möglich.) - freier Meinungsäußerung Kontaktaufnahme ohne Vorurteile - Beleidigungen/Beschimpfungen - Unehrlichkeit/Betrug etwas anderem, und zwar: ... - Anonymität im WWW gibt es nicht. - Ich weiß es nicht.“ 
swers ("freedom of expression" and "establishing contacts prejudice-free") in the second survey set, and "establishing contacts prejudice-free" was also the answer to lose the most approval. These changes might be an effect of the pupils' project participation which has led to a more critical view on the internet and its possibilities. Additionally, the GRG pupils, who were the youngest among our sample, were most likely to choose "insult/abuse" as an answer. On the contrary, the HTL pupils, who were the most tech-savvy, were most likely to choose "dishonesty/ deception." These differences are probably due to different experiences they have made online because of their differing ages and computer/internet skills.

To a related question more than half answered it was important that only friends could see photos they posted in social media, and around a quarter stated they never published photos in social media. ${ }^{21}$ This shows that the participants were quite aware of the internet's threat to their privacy.

\subsection{Reliability of information}

The survey participants were confronted with two statements: "Information on the internet is true" 22 and "Information I receive as a personal message or via email is true"23; possible answers were "always," "frequently," "sometimes," "rarely." The most common answers in both cases were "frequently" and "sometimes," which means they seem to believe in information on the internet as much as they believe in information they receive from more personal sources. Thus, they apparently think much of the reliability of information on the internet, making them rather susceptible to fake news etc.

\subsection{Internet/phone/games addiction}

As an open question, we asked: "I would say that someone is addicted to the internet, phone and/or video games, if" (first set only). ${ }^{24} 19$ pupils' answers fell into the category "enormous investment of time," 17 pupils' answers fell into the category "loss of control" and 6 referred to "social isolation."

Examples for "enormous investment of time": "... they are on the phone or internet all the time and never without. Like people posting on social network sites all the time"; "... one simply wastes all their spare time with the electronic devices"; "... they were playing with their phone for more than 6 hours a day"; "... the person is on the internet for more than 5 to 6 hours."

Examples for "loss of control": "... they lose track and control of their consumption"; “... the person's life mainly centres around this activity and there is a

21 „Wenn ich ein Bild von mir in einem Social Network veröffentliche, ist mir wichtig, dass - es nur meine FreundInnen sehen können - es alle sehen können - Mir ist egal, wer es sehen kann. - Ich veröffentliche keine Bilder in Social Networks."

22 „Informationen im WWW entsprechen der Wahrheit - immer - häufig - manchmal - selten“

23 „Informationen, die ich als persönliche Nachricht oder e-Mail gesendet bekomme, entsprechen der Wahrheit - immer - häufig - manchmal - selten “

24 „Ich würde sagen, jemand ist süchtig nach dem WWW, Telefon und/oder Videospielen, wenn:“ 
negative impact on their everyday life”; “... they freak out when they cannot use their mobile phone."

Examples for "social isolation": “... they do not have a social life outside the internet any more"; “... they spend more time in their room and/or alone."

Thus, the survey participants have properly described a range of addiction symptoms (cf. Braun, 2014). However, it remains unclear if they have been sensitized to the topic by teachers/parents/the media etc. or if it just reflects the fact that internet/phone/games addiction is very common in their environment.

\subsection{Cyberbullying}

Most pupils considered cyberbullying a "very big problem" or a "big problem," respectively. ${ }^{25}$ The data show significant differences by school $(\mathrm{F}(2,95)=10.19$, $p<.001)$ and gender $(\mathrm{F}(1,95)=22.92, p<.001)$, persisting throughout both survey sets. The GRG and HAK pupils perceived cyberbullying as a very big problem, the HTL pupils only as a big problem. Also, for the females in our sample, cyberbullying was a very big problem, whereas the males only considered it a big problem. The girls' perception of cyberbullying as a very big problem is likely a result of sexism in society, and specifically online (cf. Gill, 2012 who discusses sexism, sexualization, media and empowerment of adolescent girls).

The HTL pupils' perception of cyberbullying as only a big problem may in part be a result of their white-male privileged status, and in part a result of their tech nerdiness. For Germany, the JIM 2018 study (mpfs, 2018, p. 63) also found that girls $(9 \%)$ had been cyberbullied more often than boys $(6 \%)$, and adolescents with a lower level of education (10\%) more often than those with a higher level of education $(6 \%)$. Overall, $8 \%$ of the surveyed teenagers had been cyberbullied. Li (2006) conducted a cyberbullying study among students from three junior high schools in Canada. She found that males were more likely to bully as well as cyberbully than females (p. 164).

\subsection{Potentials of informatics/computer science}

Towards the end of the questionnaire, we asked the pupils for a ranking: "In what three areas is informatics/computer science specifically challenged, in order for our society and also your life to develop positively? (Please choose the 3 areas most important to you.)" 26 In both survey sets, the four most important areas were "securing anonymity," "ensuring data protection," "fighting cybercrime" and

25 „Cyber-Mobbing ist - ein sehr großes Problem - ein großes Problem - ein geringes Problem - kein Problem“

26 „In welchen drei Bereichen ist die Informatik/Computerwissenschaft besonders gefragt, damit sich unsere Gesellschaft und auch dein Leben positiv entwickeln können? (Bitte wähle die 3 für dich wichtigsten Bereiche aus:) - Datenschutz gewährleisten - UrheberInnenrecht schützen - das Zutreffen von Informationen gewährleisten - Medienkompetenz fördern - alles durchdringende Vernetzung des Alltags vorantreiben - Anonymität sichern - Sucht verhindern - Spaltung der Gesellschaft in KönnerInnen und NichtkönnerInnen verhindern - Gruppenzwang (z.B. durch Facebook oder WhatsApp) beseitigen - Cyber-Kriminalität bekämpfen - Cyber-Pornographie strenger regeln - Cyber-Mobbing verhindern - Beeinflussung durch Online-Werbung eindämmen“ 
"preventing cyberbullying." However, the rankings changed slightly. In the first set, "securing anonymity" ranked first (second set: rank 3), whereas in the second set, "ensuring data protection" ranked first (first set: rank 2). The prevention of cyberbullying ranked fourth in both sets. For details, see table 2 below.

Table 2. Most important potentials of informatics/computer science - percentages and ranks

set 1

Most important potentials of informatics/computer science Securing anonymity

Ensuring data protection

Fighting cybercrime

Preventing cyberbullying

$\begin{array}{cc}\text { percentage } & \text { rank } \\ 47.2 \% & 1 \\ 43.4 \% & 2 \\ 32.1 \% & 3 \\ 28.3 \% & 4\end{array}$

set 2

$\begin{array}{cc}\text { percentage } & \text { rank } \\ 36.6 \% & 3 \\ 51.2 \% & 1 \\ 46.3 \% & 2 \\ 34.1 \% & 4\end{array}$

By schools, in survey set $1 \mathrm{HTL}$ and HAK pupils were most likely to consider "ensuring data protection" important, while "securing anonymity" was equally important to all schools. Among the most important areas for GRG pupils was "eradicating peer group pressure (as happening on Facebook or WhatsApp)," which ranked low among the other schools in set 1 and among all three schools in set 2. This is likely an age effect, as younger adolescents tend to be more affected by peer pressure (see, for example, Steinberg \& Monahan, 2007; Sumter, Bokhorst, Steinberg, \& Westenberg, 2009).

A related open question read: "Which invention(s) should informatics/computer science make by all means?" 27 Answering this question was obligatory, it could not be skipped. However, only 28 of 53 answers in survey set 1, and 17 of 41 answers in set 2 can be considered actual answers. In the first set, 10 answers mention virtual reality (6) and artificial intelligence (4); 8 answers mention the improvement of data protection, cyber security and youth protection, often in the context of social media (Facebook); 2 answers mention socio-political and environmental issues; 8 answers mention varying possible inventions. In the second set, artificial intelligence is not mentioned anymore but there are still 3 mentions of virtual reality; 8 answers mention the improvement of data protection and cyber security, and - instead of youth protection - the fight against cyberbullying; 2 answers mention data backup (but possibly data protection was intended); ${ }^{28}$ 4 answers mention varying possible inventions.

\subsection{Summary}

Overall, our second survey, as compared to our first, indicates raised awareness regarding informatics and society: for example, security and privacy online are considered more important; also, internet expertise and time spent online are as-

27 „Welche Erfindung(en) sollte die Informatik/Computerwissenschaft unbedingt noch machen?“

28 In German, data protection is "Datensicherheit" whereas data backup is "Datensicherung". These two words are easily confused. 
sessed more realistically after this school year. However, factors other than our research project might have also contributed to the raise in awareness - like age (i.e. a maturing process), or public discourse. Also, it is noteworthy that we found no significant differences between the project participants and the control group (see above, section 3.1). Nonetheless, in the evaluation teacher group discussion (see below, chapter 4) the teachers mentioned that they had observed an increase in informatics-and-society knowledge due to the pupils' engagement with the subject area. Thus, the teacher group discussion supports the relevance of the tendencies shown by the survey results.

The surveys' two goals have been achieved: first, they provided us with insight into the participating pupils' socio-technological knowledge, online skills and attitudes towards informatics and society. Second, among other elements of projectbased teaching - e.g. the workshops - they confronted the participants with socio-technological issues to raise their awareness. We will further discuss the survey results with regard to related studies in chapter 5 of this article.

\section{Teacher group discussion}

For expert validation, we organised a reflection and evaluation discussion with the four participating teachers from our partner schools. There, the teachers had the possibility to talk about and reflect on crucial points of the research process and fieldwork, together with the project team. We compiled a mindmap synchronously during the group discussion, furthermore the discussion was audio-recorded for later analysis.

\subsection{Focus on the subject area informatics and society}

The teachers reasoned that informatics and society as a subject area was rather complex and abstract. Moreover, socio-political and even more so socio-technological issues are rarely part of school teaching, and thus the socio-technological focus was a little overwhelming for the pupils. Especially the younger pupils had never before been confronted with the impacts of informatics on society. Their teacher quoted them: "Aha - something like that [topic] even exists?" Also, the HTL pupils - despite their school's ICT focus - had so far only been exposed to a technical view on informatics. However, the pupils generally became aware of the existence of the topic by way of project-based learning, which included peer learning.

\subsection{Gaming and game design}

All the pupils, even those attending the HTL with a focus on game design, were inexperienced in game design. Thus, the HAK pupils decided to design board games rather than to develop concepts for computer games, which would have been possible, too. Because connecting their game ideas to informatics and society was not easy for the pupils, most of them did not spend much time on the topical focus of their games; they rather quickly researched the contents for their 
games on the internet. Nevertheless, the games they designed - if they were not quizzes or quiz-like - addressed specific problems such as social media, data security (hacking, viruses, identity theft), artificial intelligence or trust in technology. Overall, an increase in the pupils' game design expertise was noticeable.

The teachers considered the games database, that the pupils were supposed to create entries for, as a good starting point. Also, some of the girls had never played digital games before and were introduced to the medium by participating in the project. Their work on the games database revealed that the pupils' perception of learning games was rather one-sided up to that point - they only saw vocabulary trainers and so forth as games that facilitated learning. Mostly, they had not been exposed to serious games before. Another obstacle was the fact that learning in school is very much connected to grading, and assignments are perceived as (home)work. Thus, curiosity and initiative hardly arose.

\subsection{School routine as obstacle vs. motivating factors}

Although teachers are interested in alternative or new forms of teaching and learning, strict schedules and a strong focus on the content relevant for the Zentralmatura ${ }^{29}$ get in their way. Especially in the HAK and GRG, pupils were plainly not able to dedicate enough time to the project assignments. However, the project facilitated social learning and team building.

The two project gatherings brought together all participating pupils - three classes from three different schools catering to different demographics. The pupils were asked to present their own designs and provide feedback on the others'. This was, on the one hand, a difficult social situation for them. On the other hand, it was a motivating factor because they were very interested in the other youths (whom they would never have met had it not been for our project). Another motivating factor was the public presentation of the finished games at the Viennese games trade show Game City 2016. Also, the participating pupils appreciated the involvement of the researchers (as external experts) and their teachers - specifically the feedback they got from the project team and the teachers during the workshops and the project gatherings.

\section{Discussion and Outlook}

In this chapter, first we further discuss the results presented in the chapters above; second, we mention some of our project's limitations and its outlook; last, we summarize our results.

29 Austrian centralised high-school exit exam and at the same time general higher education entrance qualification. The Matura exams used to be prepared individually by the class teachers and have only been centralised in 2015 (i.e. all pupils across the country get the same written exam now). 


\subsection{Online survey}

Our sample of 57 project participants exhibits characteristics mostly in line with German-speaking youths overall. For example, the big studies on internet use of German and Austrian adolescents find that youths spend approximately 25 to 30 hours per week online (see section 2.2), while in our survey, answers range from less than 15 hours to 30 hours. However, unlike the big studies we did not crosscheck the participants' self-assessment by asking more detailed questions or drawing their attention to smartphone use and it is thus likely that at least some of them underestimated their online time. WhatsApp, YouTube and Google are by far the most popular and most used internet applications or platforms - in our survey as well as in the big studies.

In our survey, the percentage of respondents stating that they have seen content online that they had rather not seen, is quite high (39 out of 57). Also, 35 respondents stated they came across content they thought was age-inappropriate; and ten of those 35 considered this fact problematic. However, some of the bigger studies paint a slightly different picture: according to EU Kids Online II (2011), only $12 \%$ of the respondents state that experiences online made them feel uncomfortable or hurt them and according to the Oberösterreichische Jugend-Medien-Studie (EduGroup, 2017), unpleasant online experiences seem to happen rarely, in spite of the intensive use. At the same time, our project participants claimed to have learnt a variety of things online - not surprisingly especially computer skills and knowledge were mentioned a lot. Ballano et al. (2014) write about (online) learning processes:

Young people perceive that they mainly learn alone, intuitively, or through collaboration with their peers. They rarely turn to adults when they require assistance with technological matters ... It is interesting to note that these learning processes are carried out in leisure contexts, often motivated by individual interests, or as a result of participation in social capital networks ... (p. 150)

Accordingly, in our project technological literacy was also the central theme of five pupil-designed games (Kayali, Schwarz, Purgathofer, \& Götzenbrucker, 2018).

Our results show the persisting gender stereotypes regarding computers and technology: females are considered less computer apt than males by both, girls and boys. Roth-Ebner (2011) writes about prevalent perceptions of gender vis-à-vis computers and technology and concludes that stereotypes and prejudices highly shape society's view of how females and males are supposed to and actually do use computers/the internet. Specifically, technology is embedded in a society that sees gender in a binary and hierarchical way; thus, the assumption that females are less apt than males when it comes to ICT is constantly reproduced, no matter its accuracy.

Along with some of the big studies, our survey results show that the teenagers' relationship with security and privacy is fairly ambiguous. In the project's pupildesigned games, security, privacy, and surveillance (among others) were common central themes (Kayali et al., 2018). However, although teenagers tend to present themselves as critical and security-aware, their actions do not always live up to 
their words. The Shell Jugendstudie (2015) found that $84 \%$ of the respondents agreed completely or mostly with the statement: "Large corporations such as Facebook or Google want to earn money using their users' data." There is also $72 \%$ approval (completely or mostly) of the statement: "Large corporations such as Facebook or Google want to rule the internet with their services," as well as of: "I am careful with my personal data when I go online." Nonetheless, a majority actively uses social media, and although only $13 \%$ trust Facebook regarding how the company deals with their personal data, $57 \%$ use the platform "very often" or "frequently" and another $26 \%$ "occasionally" (pp. 18-19). According to EU Kids Online II (2011), half to almost two thirds of surveyed youths say they know how to block unwanted messages, ask for support online, manage privacy settings for a social network account, do a qualitative comparison of two websites, and block spam e-mails. Yet, according to the DIVSI U25 (2014), adolescents more strongly feel the need to protect their personal information (including chat messages etc.) from their "real-world" circles than to protect their privacy and data from big companies and/or state institutions. Also, they often spend only little time adjusting their social media profiles' privacy settings.

It is a little unsettling that our respondents seem to believe (any) information they receive via personal message or e-mail is just as true as (any) information on the internet. According to Hargittai et al. (2010), people of all ages have difficulty searching the internet efficiently and critically assessing the credibility of information found online. Altogether, the authors found that their participants relied heavily on brands online - for search engines as well as apart from them. Although this is not explicitly addressed in the big studies on youths' internet use, their results confirm it, nevertheless. For example, the JIM 2018 study (mpfs, 2018) asked respondents how they found needed information online: $87 \%$ answered they used Google, but also $60 \%$ watched YouTube videos, $36 \%$ consulted online versions of newspapers or magazines, $33 \%$ searched Wikipedia or comparable websites, $19 \%$ used Facebook or Twitter (pp. 52-53). In the JIM 2016 study (mpfs, 2016), there specifically was a question regarding reliability of different media: youths were asked which media (newspapers, TV, radio, internet) they would trust most in case of conflicting news coverage. $41 \%$ chose newspapers, $24 \%$ TV, $18 \%$ radio, and only $15 \%$ the internet (p. 13). Examples for websites they trust in this scenario of conflicting reporting included various German news outlets (altogether $49 \%$ - from Spiegel online: $20 \%$, to ARD.de/Tagesschau.de and ntv.de: $4 \%$ each), Google (13\%), Facebook (11\%), YouTube and Wikipedia (8\% each) (p. 14).

With "enormous investment of time," "loss of control" and "social isolation," in their (open) answers our survey participants have properly described a range of internet/games addiction symptoms (cf. Braun, 2014), showing that they are aware of the problem. Addiction and excessive use of digital media are topics that have drawn some attention from teachers, parents and the public in recent years. A study conducted in Innsbruck (Köppl, 2013), shows that there is indeed a percentage of pupils whose use can be described as excessive or addiction, although the actual numbers remain rather low. The youngest participants (10 years of age) show the highest number of excessive use $(11.5 \%)$ - but no addiction symp- 
toms -, while within the oldest group (18 years) there is no more excessive use but $1.1 \%$ show symptoms of addiction.

The majority of our survey respondents considered cyberbullying either a "very big” or a "big problem.” Livingstone, Stoilova, and Kelly (2016) as well as Jones, Mitchell, and Finkelhor (2013) suggest that cyberbullying has generally been rising since the early 2000s - however, this is at least partly due to increased internet access alone. They also point out that cyberbullying is less common than - albeit often closely linked to - traditional bullying. The study EU Kids Online II (2011) also reports that bullying more often takes place offline than online: $19 \%$ of the surveyed 9- to 16-year-olds state that they have been bullied during the previous year, but only $6 \%$ say it happened online. Furthermore, $12 \%$ admitted to having bullied someone, but only $3 \%$ did it online. Values for Austrian youths lie above the European average: $28 \%$ of Austrians claim to have been bullied, $7 \%$ of which made this experience online.

\subsection{Teacher group discussion}

By and large, society and social context are mostly neglected in Austrian schools due to the wide range of general knowledge that is needed for passing the highschool exit exam Matura (for the very similar German situation, cf. Koubek, 2005). Pupils are hardly encouraged to deal with their role in society - hence their surprise when confronted with the subject area informatics and society, as echoed by their teachers during the group discussion. One should also not forget that common discourses in contemporary neoliberalism put the individual above the society. Nonetheless, the Shell Jugendstudie (2015, p. 32) concludes: "The concept of 'society' initially seems abstract and superficial to most young people. Over the course of the discussion however, they develop surprisingly specific ideas of how our society will develop in the next five years." The study continues that adolescents indeed do have a wish to shape society (ibid.).

Apart from the welcome disruption of the school routine, our project-basedlearning approach also had the big benefit of emphasizing social and peer learning, which the participating pupils clearly appreciated. Also, the project gatherings caused all the participating pupils (from three different schools) to meet new people they would not have met otherwise: not only their socio-cultural backgrounds varied but also the areas of Vienna they inhabited and frequented. Additionally, we were able to establish game-media literacy in pupils who had not at all or hardly played digital games before - especially some of the girls.

Today, digital-media literacy is a central skill for youths and adults alike. Especially teenagers and young adults tend to overestimate their digital-media literacy. For them, intense use results directly in good knowledge and skills. For example the teenagers featured in the Oberösterreichische Jugend-Medien-Studie regard themselves as their families' internet experts (EduGroup, 2017) and the DIVSI U25 survey participants do not perceive their parents and/or teachers as suitable advisors regarding internet use because they believe they are more internet literate themselves than (most) grown-ups (DIVSI, 2014). Others (Ballano et al., 2014; Hargittai et al., 2010; Park, 2015; see also section 2.1 of this article) point out 
that individual differences in skills can be huge. Our research shows that youths are not always as competent as they like to think. Concerning our project participants specifically, their ability to connect social circumstances with technical questions can still improve further.

Despite the fact that a lot of the teams decided on their games' specific foci rather quickly and (seemingly) without thorough research or consideration, the games in the end dealt with some relevant socio-technological issues (e.g. social media, data security, trust in technology). As shown by our project, in the classroom project-based teaching is preferable to traditional approaches. Especially when it comes to complex, challenging issues such as the ambivalent relation between technology and society, independent project work by pupils offers a combination of creative freedom, social learning and mutual feedback.

\subsection{Limitations and outlook}

The participating pupils' previous exposure to technological and socio-technological issues varied a lot, with the HTL pupils having the most-evolved prior knowledge, at least as regards technology. The workshops as well as the game presentations at the project gatherings were aimed at accommodating these differences in knowledge and skills. However, the HTL pupils' advance in knowledge was also mirrored in how much time was available to us for workshops with the respective school classes on the one hand, and to the teams of pupils for the game design process on the other hand. This resulted in the fact that only the HTL pupils designed actual digital games while the pupils of the other two schools designed board games.

The rigid Austrian school system in general and the curricula in particular offer little room for distinct initiative; learning in school is too heavily connected to grading and too restricted by the need to acquire all the knowledge necessary to pass the centralised exit exam. In two of our three partner schools the pupils did essentially not have enough time to complete all their project assignments properly. The heaviest limitation for future teaching use of the informatics-and-society games designed by our project participants also lies within the school system: without a frame like our project, there are hardly any incentives for incorporating a more playful approach into regular teaching.

Apart from sufficient time and space for covering socio-political, socio-technological, socio-cultural (and so on) issues in the classroom, teachers could also benefit from further training to address these issues in a meaningful way as well as training to develop their own digital-media literacy. As Livingstone (2017) argues, being digitally connected is not an end in itself but rather needs to be purposefully integrated into the complex realities of life in the $21^{\text {st }}$ century.

For future projects, we plan to further explore the potential of game design within a project-based learning setting; the potential of games as tools for reflection, learning and personal development; and the potential of project-based teaching/learning in classrooms in general. This also means trying to further improve project schedules for the participating pupils in accordance with the realities of the school year (e.g. prioritizing entire project weeks in the beginning and end of the school year when there are no exams). 


\subsection{Summary of results}

Considering today's unprecedented media availability and use - in particular with regard to youths -, the project "Sparkling Games" sought to break new ground by showing pupils how to create content instead of just consuming it. As communication, information, entertainment and creativity are among the motivations for young people's internet use cited by several studies, and as the popularity of spending time with friends remains unbroken (cf. section 2.2), we decided to incorporate these preferences by integrating technology into school life instead of restricting its use (as is common in Austrian schools). Our chosen approach for this purpose was project-based teaching/learning, a setting in which social learning was an important factor.

Through project-based learning we managed to teach our project participants - Viennese high-school pupils aged 14 to 23 years - game design skills. Also, we managed to raise their awareness for informatics and society. They benefitted especially from the opportunity to take part in social and peer learning during the workshops and the game design process in teams; they also benefitted from being able to exchange views with pupils from diverse backgrounds at the two project gatherings and at the games trade show Game City.

\section{References}

Abt, C. C. (1970). Serious games. New York, NY: Viking.

ARD/ZDF Projektgruppe Multimedia [ARD/ZDF]. (2017). ARD/ZDF-Onlinestudie 2017: Kern-Ergebnisse [ARD/ZDF online study 2017: Core results]. Retrieved from http://www.ard-zdf-onlinestudie.de/files/2017/Artikel/Kern-Ergebnisse_ARDZDFOnlinestudie_2017.pdf

Ballano, S., Uribe, A. C., \& Munté-Ramos, R.-À. (2014). Young users and the digital divide: Readers, participants or creators on Internet? Communication \& Society, 27(4), 147-155. https://doi.org/10.15581/003.27.4.147-155

Baumgartner, P., Laske, S., \& Welte, H. (2000). Handlungsstrategien von LehrerInnen - ein heuristisches Modell [Action strategies of teachers - a heuristic model]. In C. Metzger, H. Seitz, \& F. Eberle (Eds.), Impulse für die Wirtschaftspädagogik: Festschrift zum 65. Geburtstag von Prof. Dr. Rolf Dubs. Band 26 der Schriftenreihe für Wirtschaftspädagogik (pp. 247-266). Zürich, Switzerland: Verlag SKV.

Biber, J. K., Doverspike, D., Baznik, D., Cober, A., \& Ritter, B. A. (2002). Sexual harassment in online communications: Effects of gender and discourse medium. Cyberpsychology \& Behavior, 5(1), 33-42. https://doi.org/10.1089/109493102753685863

Braun, U. (2014). Exzessive Internetnutzung Jugendlicher im familialen Kontext: Analysen zu Sozialschicht, Familienklima und elterlichem Erwerbsstatus [Excessive internet use of adolescents in the familial context: Analyses of social class, family climate and parental employment status]. Wiesbaden, Germany: Springer VS.

Brown, S. L., \& Vaughan, C. C. (2009). Play: How it shapes the brain, opens the imagination, and invigorates the soul. New York, NY: Penguin.

Cohn, R. C. (1975). Pädagogik als antizipierende Therapie [Pedagogy as anticipatory therapy]. Schweizer Schule, 62 (20), 737-763. https://doi.org/10.5169/seals-533802 
Deci, E. L., \& Ryan, R. M. (2012). Motivation, personality, and development within embedded social contexts: An overview of self-determination theory. In R. M. Ryan (Ed.), The Oxford handbook of human motivation (pp. 85-107). Oxford, England: Oxford University Press.

de Freitas, S. (2006). Learning in immersive worlds: A review of game-based learning. Bristol, England: Joint Information Systems Committee. Retrieved from https://pureportal. coventry.ac.uk/files/4017131/learning\%20in\%20immersive\%20worlds.pdf

Deutsches Institut für Vertrauen und Sicherheit im Internet [DIVSI]. (2014). DIVSI U25Studie: Kinder, Jugendliche und junge Erwachsene in der digitalen Welt [DIVSI U25 study: Children, adolescents and young adults in the digital world]. Hamburg, Germany. Retrieved from https:/www.divsi.de/wp-content/uploads/2014/02/DIVSI-U25-Studie.pdf

de Visser, R. O., \& McDonnell, E. J. (2012). 'That's OK. He's a guy': A mixed-methods study of gender double-standards for alcohol use. Psychology \& Health, 27(5), 618639. https://doi.org/10.1080/08870446.2011.617444

Drakett, J., Rickett, B., Day, K., \& Milnes, K. (2018). Old jokes, new media - Online sexism and constructions of gender in internet memes. Feminism \& Psychology, 28(1), 109-127. https://doi.org/10.1177/0959353517727560

Education Group [EduGroup]. (2017). Oberösterreichische Jugend-Medien-Studie 2017: Das Medienverhalten der 11- bis 18-Jährigen [Upper Austrian youth media study 2017: The media behaviour of 11- to 18-year-olds]. Linz, Austria. Retrieved from https:/www.edugroup.at/fileadmin/DAM/Innovation/Forschung/Dateien/Jugend MedienStudie_ZusFassung_2017.pdf

Emer, W. (2013). Historische Entwicklungslinien von Projektunterricht und Projektdidaktik in der BRD [Historical evolution of project-based teaching and didactics in the FRG]. In C. Schumacher, F. Rengstorf, \& C. Thomas (Eds.), Projekt: Unterricht - Projektunterricht und Professionalisierung in Lehrerbildung und Schulpraxis (pp. 40-62). Göttingen, Germany: Vandenhoeck \& Ruprecht.

Forschungsverbund EU Kids Online [EU Kids]. (2011). EU Kids Online II - Risiken o Sicherheit im Internet: Befunde einer empirischen Untersuchung zur Onlinenutzung von Kindern und Jugendlichen. Überblick über europäische Ergebnisse [EU Kids Online II - risks \& security on the internet: Findings of an empirical study on the online use of children and adolescents. Overview of European results]. Retrieved from http:// www.lse.ac.uk/media@lse/research/EUKidsOnline/EU\%20Kids\%20II\%20(2009-11)/ EUKidsExecSummary/AustriaExecSum.pdf

Foschi, M. (2000). Double standards for competence: Theory and research. Annual Review of Sociology, 26, 21-42. https://doi.org/10.1146/annurev.soc.26.1.21

Fridrich, C. (1994). Chancen und Grenzen des Projektlernens an österreichischen Schulen aus heutiger Sicht [Opportunities and limits of project-based learning in Austria's schools from today's perspective]. schulheft, 74/1994, 7-30.

Fromme, J., Jörissen, B., \& Unger, A. (2008). Bildungspotenziale digitaler Spiele und Spielkulturen [Educational potentials of digital games and game cultures]. MedienPädagogik, 15/16. https://doi.org/10.21240/mpaed/15+16/2008.12.22.X

Fugère, M. A., Escoto, C., Cousins, A. J., Riggs, M. L., \& Haerich, P. (2008). Sexual attitudes and double standards: A literature review focusing on participant gender and ethnic background. Sexuality \& Culture, 12(3), 169-182. https://doi.org/10.1007/ s12119-008-9029-7 
Galarneau, L. L. (2005). Authentic learning experiences through play: Games, simulations and the construction of knowledge. SSRN. https://doi.org/10.2139/ssrn.810065

Garris, R., Ahlers, R., \& Driskell, J. E. (2002). Games, motivation, and learning: A research and practice model. Simulation \& Gaming, 33(4), 441-467. https://doi. org/10.1177/1046878102238607

Gee, J. P. (2007). What video games have to teach us about learning and literacy (revised and updated edition). New York, NY: Palgrave Macmillan.

Generation What? Austria. (2016). Website. Retrieved January 16, 2018, from http:// generation-what.at/

Gill, R. (2012). Media, empowerment and the 'Sexualization of Culture' debates. Sex Roles, 66(11-12), 736-745. https://doi.org/10.1007/s11199-011-0107-1

Goldenbaum, A. (2011). Innovationsmanagement in Schulen: Eine empirische Untersuchung zur Implementation eines Sozialen Lernprogramms [Innovation management in schools: An empirical study of a social learning programme's implementation]. Wiesbaden, Germany: Springer.

Green, C. S., \& Bavelier, D. (2006). The cognitive neuroscience of video games. In P. Messaris \& L. Humphreys (Eds.), Digital media: Transformations in human communication (pp. 211-224). New York, NY: Peter Lang.

Gudjons, H. (2014). Handlungsorientiert lehren und lernen: Schüleraktivierung - Selbsttätigkeit - Projektarbeit [Active teaching and learning: Pupil activation - self-activity project work] ( $8^{\text {th }}$ ed., updated). Bad Heilbrunn, Germany: Klinkhardt.

Hänsel, D. (1997). Projektmethode und Projektunterricht [Project method and projectbased teaching]. In D. Hänsel (Ed.), Handbuch Projektunterricht (pp. 54-92). Weinheim, Germany: Beltz.

Hargittai, E., Fullerton, L., Menchen-Trevino, E., \& Thomas, K. Y. (2010). Trust online: Young adults' evaluation of web content. International Journal of Communication, 4, 468-494. Retrieved from https://ijoc.org/index.php/ijoc/article/view/636/423

Huizinga, J. (1955). Homo ludens: A study of the play-element in culture. Boston, MA: Beacon Press.

Institut für Bildungsforschung der Wirtschaft. (2011). The Austrian education system. Vienna, Austria. Retrieved from https://www.bic.at/downloads/en/brftipps/0_1_ bildungssystem_en.pdf

Jones, L. M., Mitchell, K. J., \& Finkelhor, D. (2013). Online harassment in context: Trends from three youth internet safety surveys (2000, 2005, 2010). Psychology of Violence, 3(1), 53-69. https://doi.org/10.1037/a0030309

Juhari, S. F., \& Mat Zin, N. A. (2013). Educating children about internet safety through digital game based learning. International Journal of Interactive Digital Media, 1(1), 6570 .

Juul, J. (2013). The art of failure: An essay on the pain of playing video games. Cambridge, MA: The MIT Press.

Kalaitzis, D., Valeontis, E., Delis, V., \& Fountana, M. (2010). Experiences from developing online VR environments: The "SimSafety" case study. In Proceedings of the refereed scientific conference 2010 Social Applications for Life Long Learning (SALL 2010), 4-5 November 2010, Patras, Greece (pp. 8-13). Retrieved from http://orion.westgate. gr/sall2010/documents/SALL\%202010.pdf 
Kayali, F., Schwarz, V., Götzenbrucker, G., \& Purgathofer, P. (2016). Learning, gaming, designing: Using playful participation to create learning games together with high school students. Conjunctions. Transdisciplinary Journal of Cultural Participation, 3(1). https://doi.org/10.7146/tjcp.v3i1.23645

Kayali, F., Schwarz, V., Götzenbrucker, G., \& Purgathofer, P. (2017). “Sparkling Games”: Die Gestaltung von Lernspielen zu Themen aus Informatik und Gesellschaft ["Sparkling Games": The design of learning games covering informatics-and-society topics]. In W. Zielinski, S. Aßmann, K. Kaspar, \& P. Moormann (Eds.), Spielend lernen! Computerspiele(n) in Schule und Unterricht. Band 5 der Schriftenreihe zur digitalen Gesellschaft NRW (pp. 159-170). München, Germany: kopaed.

Kayali, F., Schwarz, V., Purgathofer, P., \& Götzenbrucker, G. (2018). Using game design to teach informatics and society topics in secondary schools. Multimodal Technologies and Interaction, 2(4), 77. https://doi.org/10.3390/mti2040077

Kayali, F., Wallner, G., Kriglstein, S., Bauer, G., Martinek, D., Hlavacs, H., ... Wölfle, R. (2014). A case study of a learning game about the internet. In S. Göbel \& J. Wiemeyer (Eds.), Lecture Notes in Computer Science, Vol. 8395: Games for training, education, health and sports: $4^{\text {th }}$ International Conference on Serious Games, GameDays 2014, Darmstadt, Germany, April 1-5, 2014. Proceedings (pp. 47-58). https://doi. org/10.1007/978-3-319-05972-3_6

Kendall, L. (2011). "White and Nerdy": Computers, race, and the nerd stereotype. The Journal of Popular Culture, 44(3), 505-524. https://doi.org/10.1111/j.1540-5931.2011.00846.x

Kiili, K., de Freitas, S., Arnab, S., \& Lainema, T. (2012). The design principles for flow experience in educational games. In A. De Gloria \& S. de Freitas (Eds.), Procedia Computer Science, Vol. 15: $4^{\text {th }}$ International Conference on Games and Virtual Worlds for Serious Applications (VS-GAMES’12) (pp. 78-91). https://doi.org/10.1016/j.procs.2012.10.060

Klimmt, C. (2009). Serious games and social change: Why they (should) work. In U. Ritterfeld, M. Cody, \& P. Vorderer (Eds.), Serious games: Mechanisms and effects (pp. 248-270). New York, NY: Routledge.

Klingler, W., Feierabend, S., \& Turecek, I. (2015). Medien im Alltag junger Menschen: Befunde verschiedener Studien zur Mediennutzung Zwölf- bis 29-Jähriger [Media in young people's everyday life: Findings from various studies on twelve- to 29-year-olds' media use]. Media Perspektiven, 4/2015, 199-209. Retrieved from https://www.ardwerbung.de/fileadmin/user_upload/media-perspektiven/pdf/2015/042015_Klingler_ Feierabend_Turecek.pdf

Köppl, E. (Ed.). (2013). Internet- und Computersucht bei Jugendlichen: Erhebung zur Internet- und Computerspielnutzung bei Jugendlichen [Internet and computer addiction among adolescents: Survey on adolescents' internet and computer game use]. Innsbruck, Austria. Retrieved from http://medienwelt.tibs.at/sites/medienwelt.tibs.at/files/ upload/Finale\%20Version \%20Forschungsbericht \%203.0.pdf

Koster, R. (2004). A theory of fun for game design. Scottsdale, AZ: Paraglyph Press.

Koubek, J. (2005). Informatische Allgemeinbildung [General education in informatics]. In S. Friedrich (Ed.), Unterrichtskonzepte für informatische Bildung: Proceeding zur 11. GI-Fachtagung Informatik und Schule, 28.-30. September 2005 an der TU Dresden (Vol. P-60 of the series Lecture Notes in Informatics, pp. 57-66). Bonn, Germany: Gesellschaft für Informatik. 
Krajcik, J. S., \& Shin, N. (2014). Project-based learning. In K. R. Sawyer (Ed.), The Cambridge handbook of the learning sciences (pp. 275-297). Cambridge, England: Cambridge University Press.

Lazzaro, N. (2008). Why we play: Affect and the fun of games: Designing emotions for games, entertainment interfaces and interactive products. In A. Sears \& J. A. Jacko (Eds.), The human-computer interaction handbook: Fundamentals, evolving technologies, and emerging applications (2 ${ }^{\text {nd }}$ ed., 679-700). New York, NY: Lawrence Erlbaum Associates.

Li, Q. (2006). Cyberbullying in schools: A research of gender differences. Social Psychology International, 27(2), 157-170. https://doi.org/10.1177/0143034306064547

Linderoth, J. (2012). Why gamers don't learn more: An ecological approach to games as learning environments. Journal of Gaming \& Virtual Worlds, 4(1), 45-62. https://doi. org/10.1386/jgvw.4.1.45_1

Livingstone, S. (2017). The class: Living and learning in the digital age. In S. Tosoni, N. Carpentier, M. F. Murru, R. Kilborn, L. Kramp, R. Kunelius, ... P. PruulmannVengerfeldt (Eds.), Present scenarios of media production and engagement (pp. 55-66). Bremen, Germany: edition Lumière.

Livingstone, S., Stoilova, M., \& Kelly, A. (2016). Cyberbullying: Incidence, trends and consequences. In United Nations Special Representative of the Secretary-General on Violence against Children. (Ed.), Ending the torment: Tackling bullying from the schoolyard to cyberspace (pp. 115-120). New York, NY: United Nations. https://doi. org/10.18356/27a397d3-en

Malone, T. W., \& Lepper, M. R. (1987). Making learning fun: A taxonomy of intrinsic motivations for learning. In R. E. Snow \& M. J. Farr (Eds.), Aptitude, learning, and instruction, Vol. 3: Conative and affective process analyses (pp. 223-253). Hillsdale, NJ: Lawrence Erlbaum Associates.

Medienpädagogischer Forschungsverbund Südwest [mpfs]. (2016). JIM 2016 - Jugend, Information, (Multi-)Media: Basisstudie zum Medienumgang 12- bis 19-Jähriger in Deutschland [JIM 2016 - Youth, information, (multi)media: Basic study on media handling of 12- to 19-year-olds in Germany]. Stuttgart, Germany. Retrieved from https://www.mpfs.de/fileadmin/files/Studien/JIM/2016/JIM_Studie_2016.pdf

Medienpädagogischer Forschungsverbund Südwest [mpfs]. (2018). JIM-Studie 2018 - Jugend, Information, Medien: Basisuntersuchung zum Medienumgang 12- bis 19-Jähriger [JIM study 2018 - Youth, information, media: Basic survey on media handling of 12to 19 -year-olds]. Stuttgart, Germany. Retrieved from https://www.mpfs.de/studien/jimstudie/2018/

Michael, D., \& Chen, S. (2006). Serious games: Games that educate, train, and inform. Boston, MA: Thomson Course Technology.

Papastergiou, M. (2009). Digital game-based learning in high school computer science education: Impact on educational effectiveness and student motivation. Computers \& Education, 52(1), 1-12. https://doi.org/10.1016/j.compedu.2008.06.004

Park, Y. J. (2015). My whole world's in my palm! The second-level divide of teenagers' mobile use and skill. new media \& society, 17(6), 977-995. https://doi.org/ $10.1177 / 1461444813520302$

Popp, U. (2009). Vielfältig fördern und fordern durch soziales Lernen [Supporting and challenging in a diverse way through social learning]. In S. Appel, H. Ludwig, \& 
U. Rother (Eds.), Jahrbuch Ganztagsschule 2010: Vielseitig fördern (pp. 79-88). Schwalbach/Taunus, Germany: Wochenschau Verlag.

Rengstorf, F., \& Schumacher, C. (2013). Projektunterricht in Lehrerbildung und Bildungsdiskussion [Project-based teaching in teacher training and discussions on education]. In C. Schumacher, F. Rengstorf, \& C. Thomas (Eds.), Projekt: Unterricht - Projektunterricht und Professionalisierung in Lehrerbildung und Schulpraxis (pp. 19-39). Göttingen, Germany: Vandenhoeck \& Ruprecht.

Roth-Ebner, C. (2011). Medienkompetenz \& Genderkompetenz: Kompetenzen für das Web 2.0 [Media literacy \& gender literacy: Competencies for the Web 2.0]. Medienimpulse, 3/2011. Retrieved from https://journals.univie.ac.at/index.php/mp/article/view/ $\operatorname{mi} 352 / 572$

saferinternet.at. (2017). Jugend-Internet-Monitor 2017 [Youth internet monitor 2017]. Vienna, Austria. Retrieved February 20, 2018, from https:/www.saferinternet.at/ jugendinternetmonitor/

Salen, K., \& Zimmerman, E. (2004). Rules of play: Game design fundamentals. Cambridge, MA: The MIT Press.

Schneider-Landolf, M., Spielmann, J., \& Zitterbarth, W. (Eds.) (2017). Handbook of Theme-Centered Interaction (TCI). Göttingen, Germany: Vandenhoeck \& Ruprecht.

Schulmeister, R. (2009). Is there a net gener in the house? Dispelling a mystification. eleed, 5. Retrieved from https://eleed.campussource.de/archive/5/1587

Schulmeister, R. (2010). Deconstructing the net generation thesis. QWERTY - Rivista interdisciplinare di tecnologia, cultura e formazione, 5(2), 26-60. Retrieved from http://www.ckbg.org/qwerty/index.php/qwerty/article/view/98/69

Schumacher, C., \& Rengstorf, F. (2013). Chancen und Probleme bei der Implementation von Projektunterricht - eine Übersicht zur empirischen Unterrichtsforschung aus international vergleichender Perspektive [Opportunities and problems in the implementation of project-based teaching - an overview of empirical educational research from a comparative international perspective]. In C. Schumacher, F. Rengstorf, \& C. Thomas (Eds.), Projekt: Unterricht - Projektunterricht und Professionalisierung in Lehrerbildung und Schulpraxis (pp. 63-85). Göttingen, Germany: Vandenhoeck \& Ruprecht.

Shell Deutschland [Shell]. (2015). 17. Shell Jugendstudie: Zusammenfassung [17 th Shell youth study: Summary]. Retrieved from https://www.shell.de/ueber-uns/die-shelljugendstudie/multimediale-inhalte/_jcr_content/par/expandablelist_643445253/ expandablesection_1535413918.stream/1456210063290/d53d61c2745423456f c49b95e67d08cbd782c33a/shell-jugendstudie-2015-zusammenfassung-de.pdf

Sheng, S., Magnien, B., Kumaraguru, P., Acquisti, A., Cranor, L. F., Hong, J., \& Nunge, E. (2007). Anti-Phishing Phil: The design and evaluation of a game that teaches people not to fall for phish. In SOUPS '07: Proceedings of the $3^{\text {rd }}$ Symposium on Usable Privacy and Security, Pittsburgh, PA, USA, July 18-20, 2007 (pp. 88-99). New York, NY: ACM. https://doi.org/10.1145/1280680.1280692

Squire, K. (2006). From content to context: Videogames as designed experience. Educational Researcher, 35(8), 19-29. https://doi.org/10.3102/0013189X035008019

Squire, K., \& Jenkins, H. (2003). Harnessing the power of games in education. Insight, 3(1), 5-33. Retrieved from https://pdfs.semanticscholar.org/718e/12db4a77643b15844 19eaa8983c655cbf5f9.pdf 
Steinberg, L., \& Monahan, K. C. (2007). Age differences in resistance to peer influence. Developmental Psychology, 43(6), 1531-1543. https://doi.org/10.1037/0012-1649.43.6.1531

Steins, G., \& Haep, A. (2014). Soziales Lernen - Angewandte Sozialpsychologie für Lernende und Lehrende in Schule und Universität [Social learning - applied social psychology for learners and teachers in school and university]. Gruppendynamik \& Organisationsberatung, 45(1), 5-23. https://doi.org/10.1007/s11612-014-0234-6

Sumter, S. R., Bokhorst, C. L., Steinberg, L., \& Westenberg, P. M. (2009). The developmental pattern of resistance to peer influence in adolescence: Will the teenager ever be able to resist? Journal of Adolescence, 32/2009, 1009-1021. https://doi.org/10.1016/j. adolescence.2008.08.010

Thomas, J. W. (2000). A review of research on project-based learning. San Rafael, CA: The Autodesk. Retrieved from http://live-buckinstitute.pantheonsite.io/sites/default/ files/2019-01/A_Review_of_Research_on_Project_Based_Learning.pdf

Tocci, J. (2009). Geek cultures: Media and identity in the digital age. Publicly Accessible Penn Dissertations, 953. Retrieved from https://repository.upenn.edu/cgi/viewcontent. cgi? article $=2112 \&$ context $=$ edissertations

Traub, S. (2012). Projektarbeit - ein Unterrichtskonzept selbstgesteuerten Lernens? Eine vergleichende empirische Studie [Project work - a teaching concept of self-directed learning? A comparative empirical study]. Bad Heilbrunn, Germany: Klinkhardt.

Valcke, M., De Wever, B., Van Keer, H., \& Schellens, T. (2011). Long-term study of safe internet use of young children. Computers \& Education, 57(1), 1292-1305. https:// doi.org/10.1016/j.compedu.2011.01.010

Wagner, M., \& Mitgutsch, K. (2008). Endbericht des Projekts Didaktische Szenarien des Digital Game Based Learning [Final report of the project Didactic Scenarios of Digital Game Based Learning]. Krems, Austria: Donau-Universität. Retrieved from https:// issuu.com/michaelgwagner/docs/2008_wagner_mitgutsch_endbericht_dsdgbl

Wishart, J. M., Oades, C. E., \& Morris M. L. (2007). Using online role play to teach internet safety awareness. Computers \& Education, 48(3), 460-473. https://doi. org/10.1016/j.compedu.2005.03.003

Xenos, M., Papaloukas, S., \& Kostaras, N. (2010). The evaluation of an online virtual game environment (SimSafety) using HOU's Software Quality Laboratory. In Proceedings of the refereed scientific conference 2010 Social Applications for Life Long Learning (SALL 2010), 4-5 November 2010, Patras, Greece (pp. 63-67). Retrieved from http://orion.westgate.gr/sall2010/documents/SALL\%202010.pdf

Zillien, N., \& Hargittai, E. (2009). Digital distinction: Status-specific types of internet usage. Social Science Quarterly, 90(2), 274-291. https://doi.org/10.1111/j.1540-6237.2009.00617.x 